\title{
Ageing of chalk rocks in an underground quarry
}

\author{
N. Lafrance \& M. Souley \\ INERIS, Campus ARTEM, School of Mining, Nancy, France \\ C. Auvray \& O. Favreau \\ GeoRessources Laboratory, University of Lorraine, Vandoeuvre-lès-Nancy, France \\ V. Labiouse \\ Rock Mechanics Laboratory LMR, EPFL, Lausanne, Switzerland
}

\begin{abstract}
In the present work, an attempt has been achieved to describe the effects of ageing and of water on the hydro-mechanical behaviour of chalks from underground quarries of northern Parisian basin. Physical and mechanical properties were obtained as a function of distances from the pillar face (horizontal core drillings, from the wall to the centre) and relative humidity (Hr) of air. It has been stated that physical and mechanical properties change with depth in the pillar: the density and compressive strength of chalk tend to decrease from the pillar face (at least $1 \mathrm{~m}$ from the wall) to the centre, contrary to the classical observations on the ageing of geomaterials. Uniaxial and triaxial compression tests under controlled relative humidity put into light the sensitivity to water (and then relative humidity in the quarry) on the mechanical strength and deformability of chalks.
\end{abstract}

\section{INTRODUCTION}

Chalk rocks have been used during centuries as an easily crafted and strong building material. The shallower underground room-and-pillar quarries where the chalk rocks were extracted are now abandoned and endure the effects of time and weather, which potentially increase their risk of collapse. In order to prevent this risk, INERIS studies the rock behaviour of two partially flooded - facing water table fluctuations underground quarries in northern France (Estreux and St-Martin-le-Nœud) through in situ instrumentation implemented in 2004 and 2009 respectively (Gombert et al. 2013). The two quarries located at an average depth of $30 \mathrm{~m}$, have been exploited by the room and pillar method with extraction rate of $60-75 \%$, and then abandoned for more than a century. The original goal of the in situ characterization was to determine the impact of groundwater table fluctuations on their stability. These fluctuations lead to chemical water-chalk interaction and impact the chalk mechanical behaviour as a consequence of climate change action. Laboratory characterization is also undertaken. Nevertheless, its hydro-chemo-mechanical behaviour is not well known despite several previous studies. Due to complex interlocked phenomena acting on the mechanical behaviour of chalks, it remains necessary to address the issue with multi-scale and multi-physics approaches.
The present work is devoted to the experimental characterization of the ageing on the hydromechanical behaviour of chalk collected in underground quarries and water-chalk interactions when linked to water flooding/unflooding cycles.

\section{MATERIALS AND METHODS}

\subsection{Tested chalk}

The studied samples came from one underground chalk quarry in the Parisian Basin, from Santonian age, in the township of Saint-Martin-le-Noeud near Beauvais (Oise, Picardie, France). The work is achieved by studying samples from one pillar. The studied chalk can be regarded as a dolomitic chalk dolomite proportion occupying nearly $14 \%$ of its mineralogical composition - and is homogeneous and isotropic with a high porosity (approximately $40 \%$ ).

\subsection{Sample preparation}

All of the samples were extracted by a corer (oriented horizontally) with water as lubricant and cut once extracted perpendicularly to the stratigraphy by a saw guaranteeing parallel and smooth surfaces. All of them were sized up by a high-grade electronic calliper and 
placed at $60^{\circ} \mathrm{C}$ to constant weight to guarantee no damage and no more water in the rock. The samples were then instrumented in order to measure axial and lateral strains. Strain gauges were glued by pairs to the sample using the same material. The gauges - lateral or axial were positioned opposing each other half the length of the sample. Fully saturated samples were obtained by placing the dried samples under equilibrate water to constant weight. Partially saturated samples were obtained by placing the dried samples under imposed hygrometry using saline solutions. The sampling of the studied pillar could be decomposed into two parts:

- "ageing sampling": constituted by horizontal $120 \mathrm{~mm}$-diameter core drillings SC1 $(\mathrm{z}=2.15 \mathrm{~m}$ from floor) and $\mathrm{SC} 3(\mathrm{z}=1.70 \mathrm{~m}$ from floor). The cylindrical samples $(\mathrm{h} \approx 40 \mathrm{~mm}, ø \approx 20 \mathrm{~mm}$ ) were taken perpendicularly to the core drilling and placed in fully saturated and dry states

- "water-effect sampling": composed by blocks from the pillar face towards the heart of pillar. The cylindrical samples $(\mathrm{h} \approx 100 \mathrm{~mm}, ø \approx 50 \mathrm{~mm}$ ) were placed in dry, fully saturated and partially saturated states.

\subsection{Physical properties}

Mechanical behaviour is sorely dependent on its physical properties such as densities.

Dry $\rho_{\mathrm{d}}$, fully saturated $\rho_{\mathrm{h}}$ and partially saturated $\rho_{\mathrm{Hr}}$ density was calculated knowing the volume $\mathrm{V}_{\mathrm{T}}$ and the dry $m_{d}$, fully saturated $m_{h}$ and partially saturated $\mathrm{m}_{\mathrm{Hr}}$ masses of the sample.

For the "chalk ageing characterization" two techniques have been used in order to obtain an idea of the porosity. The easier way consisted in a mass comparison between the saturated and the unsaturated states of a same sample. The second way was to calculate porosity by use of mercury porosimeter.

\section{CONTROLLED HYGROMETRY TESTING}

\subsection{Methodology and procedure}

The aim of these tests was to determine the influence of water on the mechanical behaviour of the chalk. In order to characterize the water effect on the dolomitic chalk behaviour, mechanical tests were performed on 1 to 3 samples for several degrees of relative humidity (of air) ranged from $90 \%$ to $98 \%$; values typically encountered in situ and for different confining pressure values $(0,1$ and $3 \mathrm{MPa})$. Relative humidity $\mathrm{Hr}$ was enforced using saline solutions: at $20^{\circ} \mathrm{C}$ zinc sulphate heptahydrate $\left(\mathrm{ZnSO}_{4}, 7 \mathrm{H}_{2} \mathrm{O}\right)$, potassium sulphate $\left(\mathrm{K}_{2} \mathrm{SO}_{4}\right)$ and copper sulphate pentahydrate $\left(\mathrm{CuSO}_{4}, 5 \mathrm{H}_{2} \mathrm{O}\right)$ were used to obtain respectively $90 \%$, $95 \%$ and $98 \%$ degrees of relative humidity. Uniaxial and triaxial compression tests under imposed hygrometry conditions were carried out on samples equipped with strain gauges.

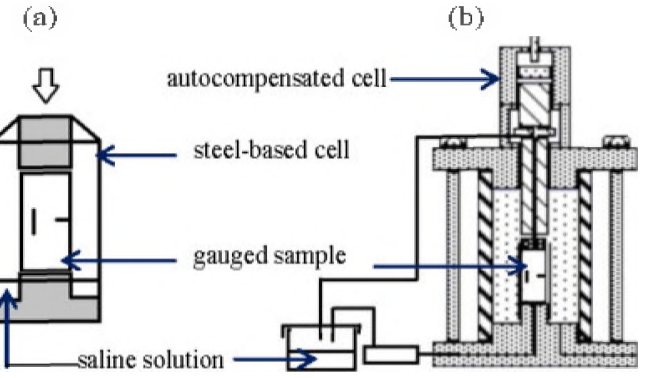

Figure 1. Experimental setup of controlled relative air humidity for mechanical tests (a) uniaxial compressive test (b) triaxial compressive cell. Temperature at $20^{\circ} \mathrm{C}$.

Table 1. Results of uniaxial compression testing and physical properties of chalk. E and $v$ are calculated using cycles in the elastic domain and are presented here as average values.

\begin{tabular}{|c|c|c|c|c|c|c|}
\hline \multirow{2}{*}{$\begin{array}{l}\text { Hygrometry } \\
\mathrm{Hr} \\
\%\end{array}$} & \multicolumn{3}{|c|}{ Mechanical properties } & \multicolumn{3}{|c|}{ Physical properties } \\
\hline & $\begin{array}{l}\mathrm{Sc} \\
\mathrm{MPa}\end{array}$ & $\begin{array}{l}\mathrm{E}^{*} \\
\mathrm{GPa}\end{array}$ & $\begin{array}{l}v^{*} \\
(-)\end{array}$ & $\rho_{\mathrm{d}}$ & $\begin{array}{l}\rho_{\mathrm{h}} \\
\mathrm{g} \cdot \mathrm{cm}^{-3}\end{array}$ & $\rho_{\mathrm{Hr}}$ \\
\hline Dry & 11 & 10.0 & 0.18 & 1.53 & - & - \\
\hline 90 & 5 & 9.9 & 0.20 & 1.54 & - & 1.55 \\
\hline 95 & 7 & 7.6 & 0.24 & 1.54 & - & 1.55 \\
\hline 98 & 5 & 10.9 & 0.21 & 1.69 & 1.91 & 1.97 \\
\hline Saturated & 2 & 11.3 & 0.19 & 1.53 & 1.88 & - \\
\hline
\end{tabular}

*average values with low standard deviation.

During uniaxial compression tests the sample is placed in a steel-based cell above the salt solution (Figure 1a) and separated from the exterior by plastic film. Triaxial compression tests were made using an imposed hygrometry autocompensated triaxial cell under drained conditions (Figure 1b) and a $1000 \mathrm{kN}$ capacity press. The tests were performed at $48 \mu \mathrm{m} / \mathrm{min}$ with 1 and $3 \mathrm{MPa}$ as a confining pressure. Unloading/loading cycling started every $2.5 \mathrm{kN}$. Finally mechanical tests were performed under controlled strain rate.

\subsection{Results}

Table 1 summarizes the results about mechanical properties of the chalk depending on the hydric state of samples (from dry to saturated) for uniaxial compression tests. These properties are then correlated to densities. Table 2-3 summarizes the results about mechanical properties of the chalk depending on the relative humidity for triaxial compression tests. The tests were carried out at 1 and $3 \mathrm{MPa}$ of confining pressure $\left(\sigma_{3}\right)$. These properties are also linked to densities. To illustrate the typical mechanical behaviour of the dolomitic chalk, Figure 2 presents the stress strains curves for three uniaxial compression tests for dry, partially $(\mathrm{Hr}=90 \%)$ and fully saturated samples. Axial strain curve is in black, lateral strain curve in 
Table 2. Results of triaxial compression and physical properties of chalk $\left(\sigma_{3}=1 \mathrm{MPa}\right)$. E and $v$ are calculated using cycles in the elastic domain and are presented here as average values.

\begin{tabular}{|c|c|c|c|c|c|c|}
\hline \multirow{2}{*}{$\begin{array}{l}\text { Hygrometry } \\
\text { Hr } \\
\%\end{array}$} & \multicolumn{3}{|c|}{ Mechanical properties } & \multicolumn{3}{|c|}{ Physical properties } \\
\hline & $\begin{array}{l}\mathrm{Sc} \\
\mathrm{MPa}\end{array}$ & $\begin{array}{l}E^{*} \\
\mathrm{GPa}\end{array}$ & $\begin{array}{l}v^{*} \\
(-)\end{array}$ & $\rho_{\mathrm{d}}$ & $\begin{array}{l}\rho_{\mathrm{h}} \\
\mathrm{g} \cdot \mathrm{cm}^{-3}\end{array}$ & $\rho_{\mathrm{Hr}}$ \\
\hline Dry & 11 & 11.1 & 0.19 & 1.53 & - & - \\
\hline 90 & 11 & 13.6 & 0.17 & 1.74 & 2.01 & 1.76 \\
\hline 95 & 9 & 12.1 & 0.44 & 1.62 & 1.93 & 1.86 \\
\hline 98 & 6 & 8.9 & 0.32 & 1.54 & 1.85 & 1.87 \\
\hline Saturated & 6 & 9.4 & 0.19 & 1.53 & 1.88 & - \\
\hline
\end{tabular}

*average values with low standard deviation.

Table 3. Results of triaxial compression and physical properties of chalk ( $\left.\sigma_{3}=3 \mathrm{MPa}\right)$. E and $v$ are calculated using cycles in the elastic domain and are presented here as average values.

\begin{tabular}{|c|c|c|c|c|c|c|}
\hline \multirow{2}{*}{$\begin{array}{l}\text { Hygrometry } \\
\mathrm{Hr} \\
\%\end{array}$} & \multicolumn{3}{|c|}{ Mechanical properties } & \multicolumn{3}{|c|}{ Physical properties } \\
\hline & $\begin{array}{l}\mathrm{Sc} \\
\mathrm{MPa}\end{array}$ & $\begin{array}{l}\mathrm{E}^{*} \\
\mathrm{GPa}\end{array}$ & $v^{*}$ & $\rho_{\mathrm{d}}$ & $\begin{array}{l}\rho_{\mathrm{h}} \\
\text { g.cm } \mathrm{cm}^{-3}\end{array}$ & $\rho_{\mathrm{Hr}}$ \\
\hline Dry & 11 & 11.6 & 0.18 & 1.53 & - & - \\
\hline 95 & 7 & 12.4 & 0.26 & 1.61 & 1.89 & 1.88 \\
\hline 98 & 6 & 20.2 & 0.22 & 1.58 & 1.89 & 1.91 \\
\hline Saturated & 10 & 19.1 & 0.27 & 1.53 & 1.88 & - \\
\hline
\end{tabular}

*average values with low standard deviation.

dark grey and volumetric strain curve in light grey. The scale was standardized to compare all the curves.

\subsection{Discussion}

Physical properties of the dolomitic chalk can be called standards similarly to other types of chalk such as Hardivilliers chalk (Hjuler et al. 2009) and Haubourdin chalk (Nadah et al. 2013).

The objectives of this series of tests were to evaluate the sensitivity of the dolomitic chalk when in contact with water. Although further tests are still ongoing at the time of writing, it appears that for uniaxial compression tests, the compressive strength of the dolomitic chalk decrease with wetting (Figure 2) and presents a seemingly abrupt transition at the last stages of wetting to complete saturation (Table 1). This evolution of $\mathrm{Sc}$ according to $\mathrm{Hr}$ is identical to those encountered in the literature for some geomaterials, particularly for chalks as shown in Figure 3 (Watelet, 1996). However static Young modulus E doesn't seem to evolve with water content considering uniaxial compression tests alone - like Poisson's ratio $\nu$. There is no loss of its stiffness when partially then fully saturated with water. The dolomitic chalk exhibits a brittle type mechanical behaviour. Compare to other types of chalks - such as Lixhe (Shroeder et al. 2003, Homand \& Shao 2000) or Estreux chalk (not

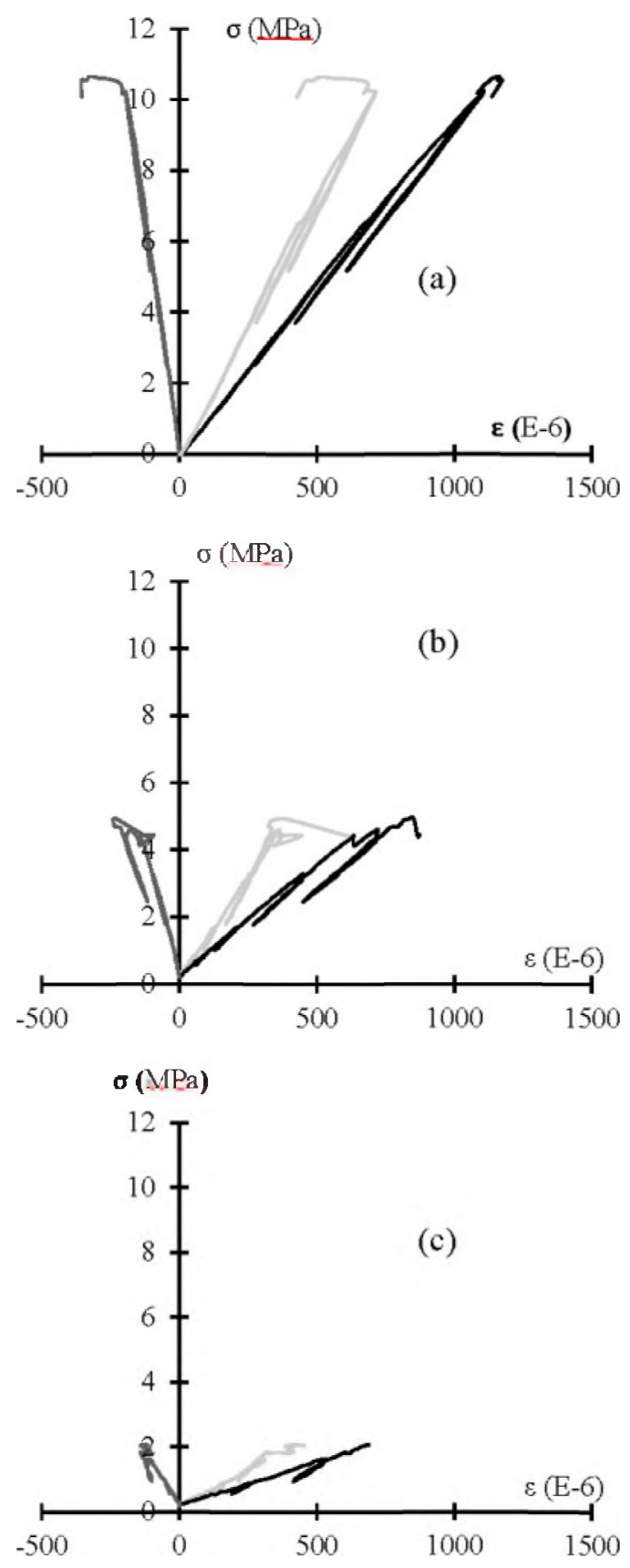

Figure 2. Stress-strains curves of uniaxial compression tests as a function of hydric state of sample (a) dry, (b) partially saturated $(\mathrm{Hr}=90 \%)$, (c) fully saturated.

presented herein) - there is no plastic stage between elastic domain and failure (pic strength) (Figure 2a). This characteristic can be linked with its mineralogy, dolomite crystals tougher (in terms of deformability) than calcite crystals and less sensitive to water. However the range of this plastic stage - almost non-existent at dry state - increases with wetting. 


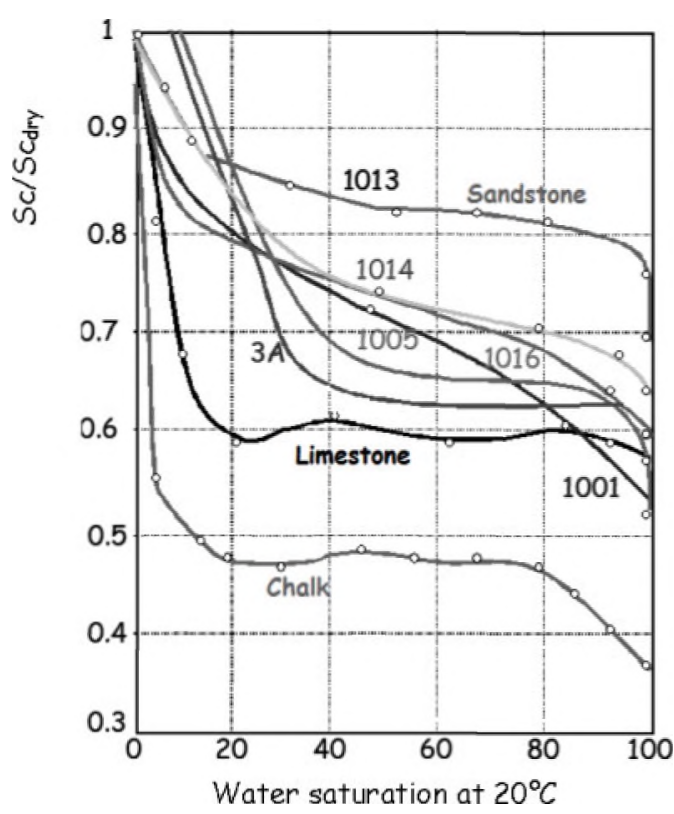

Figure 3. Compressive strength ratio versus water saturation degree for different geomaterials such as limestone, sandstone or chalk from Watelet (1996).

Table 4. Total mercury porosity for SC3 core drilling samples.

\begin{tabular}{llll}
\hline Depth $(\mathrm{cm})$ & 0 & 120 & 240 \\
\hline Porosity n $(\%)$ & 46.4 & 46.0 & 43.3 \\
\hline
\end{tabular}

With water, the dolomitic chalk tends to present a more ductile mechanical behaviour, like the previously mentioned chalks (Lixhe or Estreux).

Generally speaking, for a given $\mathrm{Hr}$ degree $(0,90 \%$, $95 \%, 98 \%$ and $100 \%$ ), compressive strength increase with the confining pressure (Table $2-3$ ). For a given $\sigma_{3}$, variation of $\mathrm{S}_{\mathrm{c}}$ with respect to $\mathrm{Hr}$ is qualitatively identical to that discussed under uniaxial conditions (except the test: $\sigma_{3}=3 \mathrm{MPa}$ and $\mathrm{Hr}=100 \%$ ). The exception of test at $3 \mathrm{MPa}$ of confining pressure under saturated conditions can be explained by the fact that water puts pressure onto the porous media and as a result there is no "vacuum" in the sample.

Finally, for the rest of unsaturated state, the mechanical behaviour under triaxial conditions follows the same trend as the unconfined ones.

\section{AGEING EFFECTS TESTING}

\subsection{Methodology and procedure}

In order to characterize the ageing of chalk - in saturated and unsaturated states - SC1 and $\mathrm{SC} 3$ core drillings were mapped: each sample was extracted depending of its range inside the pillar. This methodology has been previously applied on gypsum (Auvray
2003, Auvray et al. 2004) and iron ore (Grgic 2001, Grgic et al. 2001). The sampling collection went every $10 \mathrm{~cm}$ from the face to the heart of pillar. Then for each depth, physical properties such as density and matrix structure are obtained. It gave us the distribution of physical and mechanical properties inside the pillar depending on the distance (from the pillar face to the centre) and the stratigraphy.

SEM analysis is performed on mirror polished samples at the depths of 0,120 and $240 \mathrm{~cm}$ for the $\mathrm{SC} 3$ core drilling. Mercury porosity is also measured at the same distances.

Physical - such as density - and mechanical properties are then presented in a diagram depending on the depth in the pillar.

Because of the size of the samples, uniaxial compression tests were carried out using a $5 \mathrm{kN}$ capacity press under a constant displacement rate of $30 \mu \mathrm{m} / \mathrm{min}$.

\subsection{Results}

Figures 4-5 show how chalk physical and mechanical properties evolve depending on the depth in the pillar. Each point represents one sample. The diagrams compressive strength (Figure 4 showing difference between the edge and centre of pillar) - are presented as follow: i) SC1 core drilling samples in dry state: the dolomitic chalk is more resistant at the edge than the inside pillar; ii) $\mathrm{SC} 3$ core drilling samples in dry state: it can be subdivided into two parts (depths ranged between 0 and $100 \mathrm{~cm}$ where $S c$ presents a very slight decrease and range from 100 and $300 \mathrm{~cm}$ where $\mathrm{Sc}$ decrease is more evident); iii) SC3 core drilling samples in a fully saturated state: the same as SC1 core drilling dry samples.

The same goes for density diagrams. The scattering of measurements is also more significant at the edge than at the inside pillar.

Table 4 summarizes mercury porosity for distances of 0,120 and $240 \mathrm{~cm}$ from the pillar edge, in the case of SC3. Similarly porosity increases from the inside pillar to the edge for SC1. No clear trend shows on Figure 5 for SC3 dry samples density. For SC1 dry samples and SC3 saturated samples, a tendency is however clearly shown.

Figure 6 shows the difference between the distances 0,120 and $240 \mathrm{~cm}$ for $\mathrm{SC} 3$ regarding the microstructure of the rock matrix. The scale on each SEM photographs represents $2.5 \mu \mathrm{m}$. The crystals are well defined - almost holomorphic - with different sizes at the pillar wall (at the pillar wall) and rougher at the inside pillar (depth of $240 \mathrm{~cm}$ ) - as if they were eaten up - with almost identical sizes. The depth of $120 \mathrm{~cm}$ can be seen as intermediary.

\subsection{Discussion}

Comparing SEM photographs (Figure 6) with Table 4, the mercury porosity and rock matrix microstructure 

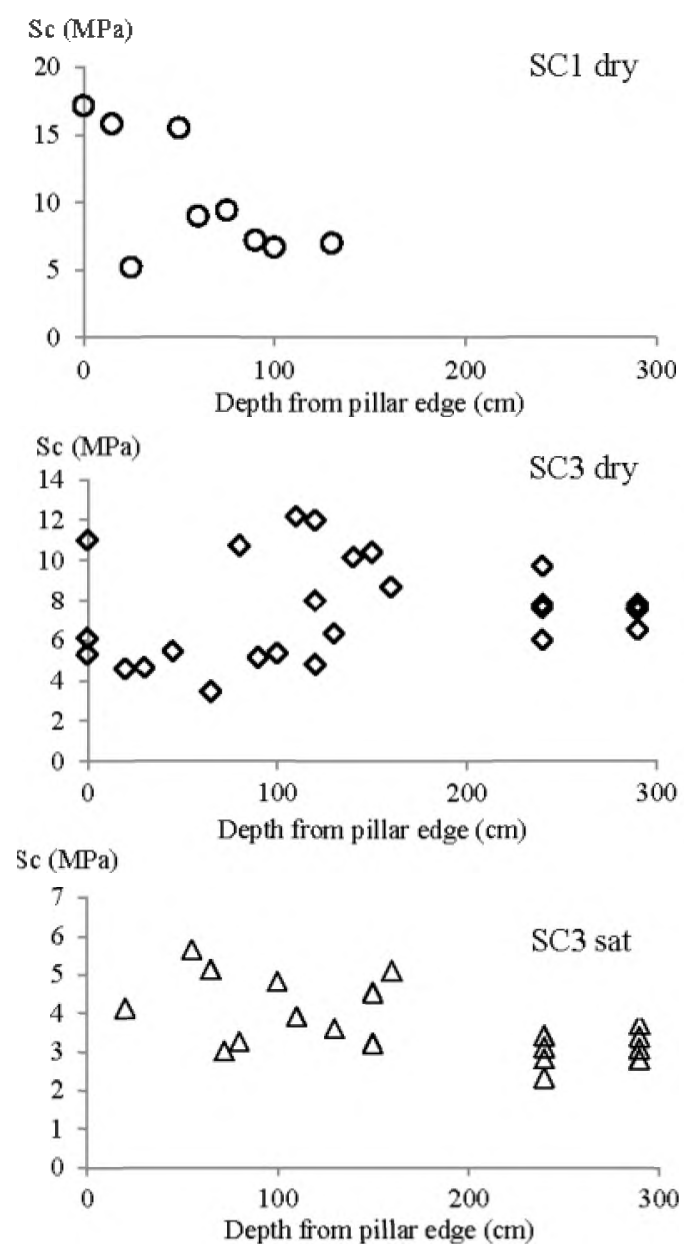

Figure 4. Ageing uniaxial compressive strength versus depils (from pillar face) on dry and/or saturated samples of $\mathrm{SC} 1$ and $\mathrm{SC} 3$ core drillings.

are well associated. The crystals were dissolved preferentially at the centre than at the wall where chalk is exposed to air transport.

However, results on Figures 3-4 according to other geomaterials like gypsum and iron ore, tends to show a very liglit contrary trend. Ageing of chalk seems to be of no standards. But the tendency is not that clear for SC3 dry samples compared to SC1 dry and SC3 fully saturated samples. For iron ore ageing is partly shown by redox reactions (Grgic et al. 2013, Dagallier et al. 2002). For gypsum (Auvray et al. 2004, Hoxha et al. 2006), ageing is partly shown by traces of dissolution. For the dolomitic chalk dissolution traces (third photo on Figure 5) are well defined but occur at the inside pillar instead of the edge - as not seen for gypsum. The parting in the results shown in Figure 4 for SC3 dry samples may be explain by micro-cracking phenomena with an increase of the porosity.

The compressive strength tends to be weaker where the dolomitic chalk seems to be more compact. This

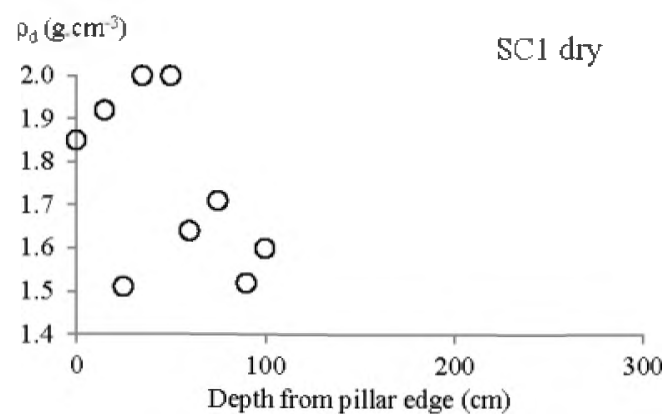

$\rho_{\mathrm{d}}\left(\mathrm{g} . \mathrm{cm}^{-3}\right)$

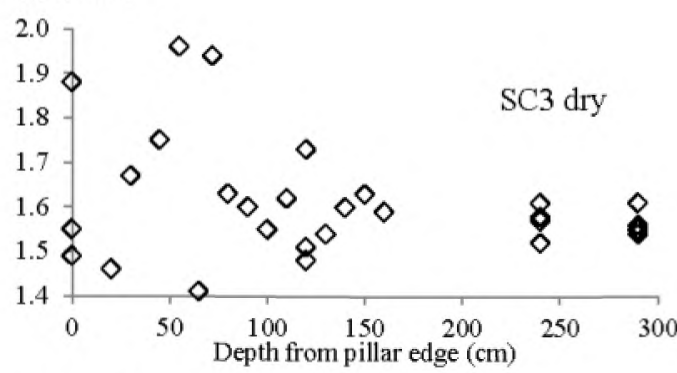

$\rho_{\mathrm{h}}\left(\mathrm{g} \cdot \mathrm{cm}^{-3}\right)$

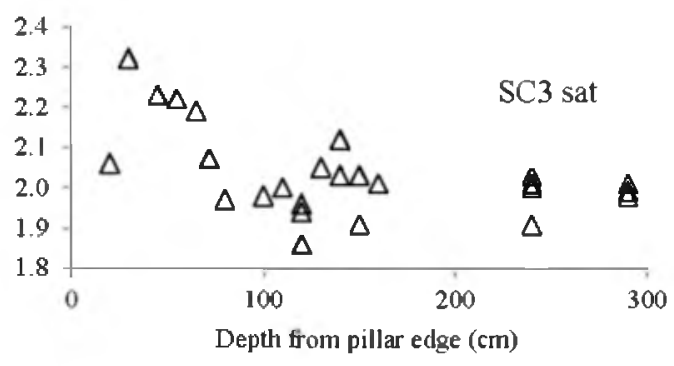

Figure 5. Densities versus depth from pillar edge on dry and or saturated samples of $\mathrm{SC} 1$ and $\mathrm{SC} 33$ core drillings.

possible contrary trend could be due to more important water (liquid) circulation at the centre than in the vicinity of pillar wall: based on in situ measurement (Gombert et al. 2013) relative humidity cyclically fluctuates at the edge and stabilizes at the centre of the pillar: the edge and the inside pillar are not subjected to the same hydric conditions. The detroying of electrostatic bondings - connecting crystals to each other - is one of the numerous phenomena governing the degradation of the mechanical behaviour of chalks (Shroeder 2002, Shroeder et al. 2003, Homand \& Shao 2000). It generally occurs when chalk is in contact with the polar molecules of water.

As samples are small, a possible scale effect is not to be spread, especially in order to explain the parting in the results of density and compressive strength. The tendency is also not totally clear.

The hypothesis risen to explain the clear distinction between edge - regarding the matrix structure is that the main water transport - with the highest velocity - occurring in the pillar is gravity, but it may not exclude the very-low-velocity transport of water 

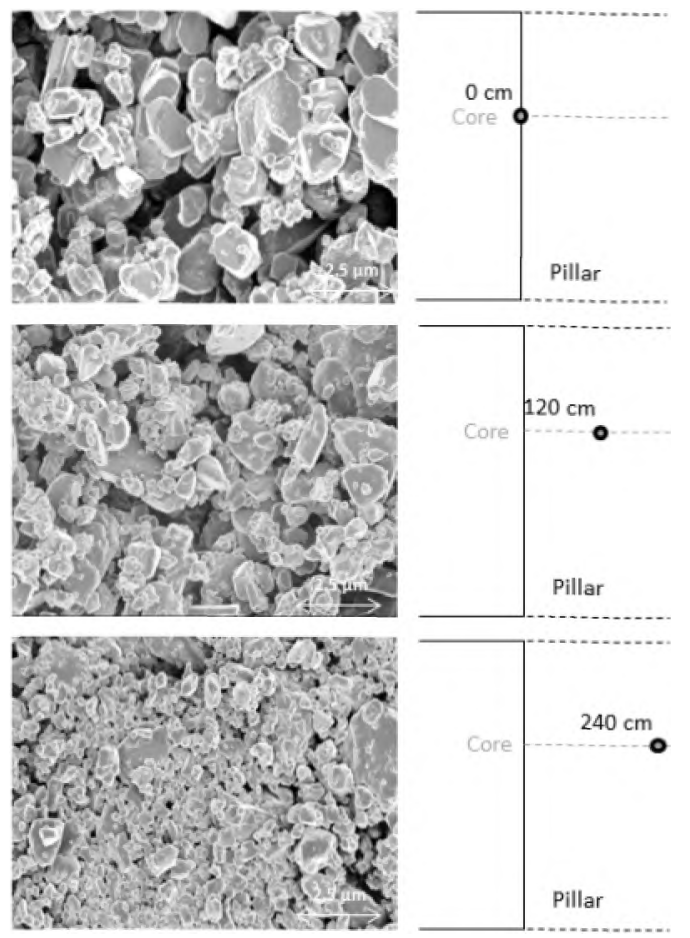

Figure 6. SEM analysis on mirror polished samples illus I rating the difference between the edge and centre of the pillar ( $\mathrm{SC} 3$ core).

occurring transversely. The main mechanism may tend then to be more of the chemo-hydric type than the chemo-mechanical-hydric ones.

\section{CONCLUSION}

Relating to water effect on chalk behaviour, uniaxial and triaxial compressive tests under imposed humidity conditions highlight the sensitivity to water of the dolomitic chalk and its deformability depending on relative humidity in the quarry. According to Gombert et al. (2013), it could be expected a greater impact by climate change with its action on ageing in abandoned mines. Uniaxial and triaxial compression testing with other relative air humidity degrees is ongoing, and goes from degrees $36 \%$ to $85 \%$ in order to complete the data base of Saint-Martin-le-Noeud site.

Relating to ageing of chalk, although further tests are still ongoing at that time, initial results suggests that water (liquid) circulation is more important at the centre than in the vicinity of pillar wall. At this step of the study, the possibly contrary tendency shown on the results has yet to be substantiated: complementary studies on other core drillings and parameters such as dynamic elastic modulus - with the help of speed velocity - must be characterized to complete the results. Nevertheless, ageing of chalk rock in underground quarries seems to be of the nonstandard-type and sent more apart chalk rocks from other geomaterials.

\section{REFERENCES}

Auvray C. 2003. Vieillissement et comportement rhéologique du gypse. PhD Thesis INPL.

Auvray C., Homand F.. Sorgi C. 2004. The aging of gypsum in underground mines. Engineering Geology 74. 183-196.

Dagallier (i.. Grgic D.. Homand F. 2002. Mineralogical and microtextural characterisation of the anthropic-origin ageing of iron ore in Lorraine (France). Comptes Rendus Geoscience 334, 455-462.

Gombert P., Auvray C.. Al Heib M., 2013. In-situ and laboralory lests to evaluate the impact of water fluctuations on stability of underground chalk mines. Proceedings of the 14th International Symlposium on Water-Rock Interaction. WRI 14. Avignon, France. June 09-14.

Grgic D. 2001. Modélisation du comportement à court terne et à long terme des roches de la formation ferritêre Lorraine. PhD Thesis INPL

Grgic D.. Homand F., Dagallier G. 2001. Ageing of Lorraine (France) abandoned iron mines. Rock Mechanics: a challenge for society. ISRM Reg EUROCK Symposium on Rock Merhanirs. Espoo, Finland. June 04-07. 825-830.

Grgic D.. Giraud A.. Auvray C. 2013. Impact of chemical weathering on micro/macro-mechanical properties of oolithic iron ore. Int. J. of Rock Mech. \& Min. Sc. 64, 236-245.

Hjuler \& Fabricius IL. 2009. Engineering properties of chalk related to diagenetic variations of upper cretaceous onshore and offshore chalk in the North sea area. J Petrol Sci Eng. 68, 151-70.

Homand S., Shao, J.F. 2000: Mechanical behaviour of a porous chalk and effect of saturating fluid. $I n t$. I. of Mechanics of Cohesive-Frictional Materials. 5, 583-606.

Hoxha D., Homand F., Auvray C. 2006. Deformation of nalural gypsum rock: Mechanisms and questions. Engineering Geology 86, 1-17.

Nadah J., Bignonnet F, Davy C.A., Skoczylas F., Troadec D., Bakowski S. 2013. Microstructure and poro-mechanical performance of Haubourdin chalk. Int. J. of Rock Mech. \& Min. Sc. 58, 149-165.

Schroeder C.2002 Du coccolithe au réservoir pétrolier: approche phénoménologiqueducomportement mécanique de la craie ‘n vue de sa modélisation à différentes échılles. $\mathrm{PhD}$ Thesis in Applied Sciences. Universily of Liège.

Schroeder C. (Coordinator) 2003. Mechanical behaviour of partially and multiphase saturated chalks and fluidskeleton interaction: Main factor of chalk oil reservoirs compaction and related subsidence. Final report of the EU project (PASACHALK2).

Watelet J.-M., 1996. Méthode d'analyse et diagnostic des conditions de stabilité des carrières souterraines. Engineering Diploma Work. ISAM-SNAM. Paris. 